\title{
NUCLEAR STATE LIABILITY FOR DAMAGE RESULTING FROM NUCLEAR ACTIVITIES
}

\author{
Lilian Letícia Nieri Madi ${ }^{*}$, Gian-Maria Agostino Angelo Sordi', Edmir Netto de Araújo² \\ ${ }^{1}$ Instituto de Pesquisas Energéticas e Nucleares (IPEN / CNEN - SP), São Paulo, SP, Brazil \\ ${ }^{2}$ Faculdade de Direito da Universidade de São Paulo - FDUSP, São Paulo, SP, Brazil
}

\begin{abstract}
Much has already been seen in the world regarding the damage that may result from an accident in nuclear power plants. In the event of an accident that causes effective damage, either to the environment or to the population, both the Brazilian and foreign standards predict liability for remedying. The Brazilian Federal Constitution of 1988 determines the competence of the Union to operate nuclear services and installations, being State monopoly activities related to nuclear material and its derivatives. Besides that, FC/88 attributed liability stricto sensu for nuclear damage. The Vienna Convention on Civil Liability for nuclear damage, dated May 21, 1993, which was promulgated in Brazil by Decree No. 911/1993, provides that the operator is responsible for nuclear damages, in the case of Brazil, the operator is the State entity (Federal Autarchy) responsible for the operation. Thus, in cases of nuclear damage, the State should be held liable objectively. And here issues begin to arise such as: Is the State always responsible? Is there any possibility of exclusion of the State's liability? This paper aims to analyze the constitutional text and the infra-constitutional rules in an attempt to answer these and other questions without, however, intending to exhaust the subject.
\end{abstract}

Keywords: Brazilian Environmental and Nuclear Laws, civil liability, strict liability of the State

\section{INTRODUCTION}

First of all it must be said that the text was written based on Brazilian law and doctrines, emphasizing that Brazilian law is based on the Vienna Convention on Civil Liability for Nuclear Damage of 05/21/1963, so that, except to the specificities of each country, those who adopt the aforementioned convention has the same treatment for such damages as Brazilian law.

Liability "is the obligation of compensation or reparation by the direct or indirect culprit of the damage caused, that is, those who are responsible for the damaging action or omission to the patrimony affected by them" [1].

Yussef Said Cahali, as to the civil liability of the State, says that it is "the legal obligation, imposed on it, to reimburse the damages caused to third parties by its activities" [2].

The responsibility of the State has historically evolved from a theory of absolute irresponsibility, through subjective responsibility (still accepted in certain hypotheses) to the theory of objective State responsibility.

Thus, it is broadly assumed today that the Public Administration is objectively responsible for damages caused. What generates a great deal of discussion is the type of objective responsibility to which it is subjected, with various theories arising in the doctrine.
Within the scope of environmental law, the objective responsibility of the State for environmental damage is adopted, and there is also much discussion in this field of law regarding the theory of risk adopted for the liability of the agent causing the damage.

Regarding the damage caused by activity involving nuclear/radioactive material, the majority position of the doctrine, as will be demonstrated, is not compatible with the legislation in force.

\section{Civil LIability ReQuirements}

The doctrine diverges as to the requirements for setting the duty to indemnify. However, three of them often appear as their assumptions: action (or omission), damage and causal link.

\subsection{Action}

Action is human conduct which may be either commissive or omissive, that is, it is a doing (practice of an act that should not be performed) or a not doing (failure to do something that should have been done).

\subsection{Damage}

Damage is the loss generated as a result of the action (commissive or omissive).

There must be real proof of injury so that the duty to indemnify arises.

*lili_madi@hotmail.com 
Carlos Alberto Bittar states that "damage is the reimbursable injury experienced by the injured party. It is translated into concrete, by the patrimonial decrease (...) that someone suffers by virtue of the action triggered by the agent, reaching both elements of pecuniary character, as of moral nature (but susceptible to economic expression), at last, any possible damage. (...) the damage must be: a) current; b) certain (defined); c) personal (in the person of the injured party); and d) direct (resulting from the action)." [3]

The payment of the indemnity is conditioned to proof of on- or off-balance sheet damage supported by someone. [4]

\subsection{Causal link}

The causal link is the connection between the action and the damage, that is, the harmful event must result from the action, either directly or as its foreseeable consequence. [3]

There are several justifying theories of the causal link. Doctrine and jurisprudence [5] have preferred, to justify the nexus in civil liability, the theory of adequate causality developed by Von Kries and Von Bar.

According to this theory, the cause is a potentially suitable and appropriate condition to generate a harmful event. That is, it is a cause all antecedents that is a typical factor, relevant to the harmful event, maintaining with it a relation of constancy, as what generally happens [4] [6].

Explaining better, it is considered cause a certain fact or behavior that is adequate to produce a certain result, generate a certain consequence, assign a result to a conduct. For example, a factory, in an irregular manner, dumps chemical components on a ground. These components penetrate the ground and reach a water table that supplies a certain city. People get sick because of it. To hold the factory accountable, it will be necessary to prove that the cause of the disease in the population was the dumping of chemical components.

\subsubsection{Excluding and mitigating of the causal link}

The State ceases responding for the damage or responds in an attenuated way when it occurs due to: fortuitous events or force majeure, exclusive fault of the victim, exclusive fault of the third party (excludes the liability) and concurrent fault of the victim (mitigates the liability).

\section{ObJective Responsibility Of The State - Risk THEORIES}

The Federal Constitution foresees two rules: objective State responsibility and subjective liability of the public agent (article $37, \S 6, \mathrm{CF}$ ).

By objective theory the responsibility is independent of the proof of culpability.

Article 37 (...)

Paragraph 6 - Legal entities governed by public law and those by private law that provide public services will be liable for damages caused by their agents, as such, to third parties, with the right of recourse against those responsible in cases of malice or fault. [7]
The Civil Code, in the single paragraph of art. 927 also adopts the objective liability for the risk of the causer of the damage:

Article 927. He who, by an unlawful act (articles 186 and 187), causes harm to another, is obliged to repair it.

Single paragraph: There will be the obligation to repair the damage, regardless of fault, in cases specified by law, or when the activity normally developed by the author of the damage implies, by its nature, a risk to the rights of others. [8]

Although there is no express provision of the risk modality attributable when applying the objective liability, the doctrine diverges, the main ones being: administrative risk theory and integral risk theory.

\subsection{Theory of the administrative risk}

By this theory, there is the obligation to indemnify the damage only by the practice of the harmful and unjust act, not speaking of the fault of the administration or its agents; it suffices the proof, by the victim, of the damaging and unjust fact due the action or omission of the Public Power. It is based on the risk that public activity entails for those administered and on the possibility of causing damage to certain members of the community. [9]

The theory of administrative risk, despite dispensing the proof of management's guilt, admits exclusion of liability. [9]

\subsection{Theory of the integral risk}

The theory of integral risk holds liable for damages undergone by third parties, even if there is no causal link between the conduct of the administration and the damage suffered by a third party and even if, as said, the victim has given cause to the damage by their exclusive act. [10]

That is, the obligation to indemnify is inherent to the activity exercised, not considering causal link or exclusion of liability.

This is the theory that has been adopted by the "STJ" (Superior Court of Justice) in the case of liability for environmental damage, however, the Higher Court considers the causal link as a binding factor between the risk and the act. [11]

\subsection{Theory of the risk created}

By the theory of risk created, it is enough that one person, by his/her activity, creates risk for another and of that results the damage, for the obligation of indemnifying to arise, being indispensable here that the damage has been caused by the activity developed by the agent. Even if the activity causing the damage is lawful, there will be an obligation to indemnify, without questioning as to guilt or possible profit arising from that activity. [12]

As to this theory, it is required the dangerousness, not being fitting to include other factors not derived from the activity itself considered (activity developed by the agent that is being considered for the case). The solution would be sought from the theory of adequate causality, which, among the factors antecedent to the damage, seeks to identify that one in conditions of actually having produced it. [13] 


\subsection{Theory of activity risk}

In the classification of objective liability based on risk, the nature of the activity exercised by the agent should be considered whether it is deemed dangerous or not dangerous.

The dangerous activities, exactly because they are dangerous, receive different treatment in proper laws. In them, the basis of liability is the risk. [3]

This responsibility is foreseen in the already transcribed single paragraph of art. 927, of the Civil Code.

The notion of risk is independent of guilt, being the simple cause, the simple exercise of the activity is enough in order to compensate for the damage resulting from it [3], without the need to question whether the explorer eventually acted negligently or recklessly. [13]

Thus, considering the activity as dangerous in the specific case, the agent responds by the simple risk, and it is enough that the victim proves the causal link, where subjective exclusions are inadmissible. [3]

For Bittar, nuclear activities represent the maximum degree of risk exacerbation and, therefore, are subordinated to their own legal structuring and peculiar liability regime. [3]

\section{Civil ENVIRONMENTAL LIABILITY}

\subsection{Environmental Objective Liability - risk theories}

José Renato Nalini [14] affirms that full objective responsibility is enshrined in paragraph 3 of article 225 of the Federal Constitution:

Article 225 (...)

$\S 3$ Conducts and activities considered harmful to the environment shall subject the offenders, individuals or legal entities, to criminal and administrative sanctions, regardless of the obligation to repair the damage caused. [7]

Before being forecast in the Federal Constitution, it was already envisaged by law.

The objective civil liability for environmental damage arose for the first time with the Decree 79,347 of 1977 [15], which promulgated the International Convention on Civil Liability for Oil Pollution Damage. [2]

Later, there was the promulgation of the Law of the National Environmental Policy, Law no. 6,938 / 1981 [16], which, in $\S 1$ of art. 14, provides the objective liability of the polluter.

By this law, the responsibility is objective, but based on the risk of the activity.

The law, although moving away from the discussion of malice or fault, requires the causal link between the activity (in case of the responsibility for the pollution) and the damage resulting from it. [13]

Although it is not argued that the civil liability for environmental damage is objective, there is dissent in the doctrine as to the risk theory to be adopted, ranging between integral risk or created risk. [17]

\section{2. - Exclusion of responsibility in the}

environmental field.

The acceptability or not of exclusions depends on the risk theory adopted. That is, for those who adopt the theory of integral risk there is no possibility of an allegation of exclusion of responsibility (majority doctrine), while for those who adopt the theory of risk created (or risk of activity), it would be possible to make use of excluding factors.

For example, assuming that there is an armed conflict between Brazil and another country and that one of its nuclear power plants is the target of this conflict and its results in the release of products harmful to health in the air and contaminate the environment. For those who adopt the theory of risk created or the risk of activity, it is possible to claim the presence of an exclusion of liability foreseen by law. In the case of Brazilian law, there is express provision in the law (Art. 8 of Law 6.453 / 1977) saying that excludes the liability of the operator the nuclear accident caused directly by armed conflict. Therefore, for those who adopt this theory (risk created or risk of activity), there would be no duty of the operator to compensate the damages caused.

However, for those adopting the theory of integral risk, there would be no possibility of an allegation of exclusion of liability, so the operator would have a duty to indemnify even if the damage was caused as a result of armed conflict.

One of the arguments used to justify the integral risk theory is the fact that, by legal hermeneutics, any exception to the rule must be expressly forecast in Law and, moreover, should be interpreted restrictively. As in the case of environmental or related legislation, there is no provision for exclusionary causes of liability for environmental damage, it is not possible to extend to the Environmental Law those provided for the Private Law, since these are antagonistic legal regimes (objective and subjective, respectively) and, therefore, incompatible. [13]

For those who understand that it is not an integral risk, it would be possible to exempt the liability of the agent if one of the exclusions is present.

\section{3 - Liability of the damage causer - solidarity}

The National Environmental Policy Law (Law 6,938 / 81) defined those responsible for environmental damage item IV of Article 3:

Article 3 - For the purposes foreseen in this Law, the following definitions apply:

IV - polluter, the natural persons or legal entity, of public or private law, responsible, directly or indirectly, for activity causing environmental degradation; [16]

Therefore, the damages must be, initially, borne by those who directly have caused or, in some way, contributed to cause or aggravate the damage. [13]

The Civil Code, in article 265, deals with solidarity stating that it is not presumed, but, it must derive from the law or from the will of the parties.

In the environmental field, solidarity would be a logical consequence of the adoption of objective responsibility by law. As seen, in principle, responsible for the damage the one who caused it, but in case there 
is more than one causer (cause and con-cause), all will be jointly and severally liable, i.e., the solidarity would arise from the provisions in the art. 942 of the Civil Code. [13] [18]

Article 942. The assets of the person responsible for the offense or violation of the rights of others shall be subject to compensation for the damage caused; and, if the offense has more than one perpetrator, all of them will be jointly and severally liable for the reparation. [8]

Moreover, the fact that it is not possible to identify who initiated the damage does not exempt from liability what is demanded to indemnify. That is, both the one who directly gave cause to the damage and the one who may indirectly be considered causative of the damage are responsible, jointly and severally for the obligation of repairing the damage in its entirety, because without him/her the damage might not have occurred. [13]

The State may also be held responsible through its direct and indirect bodies. [19] And this accountability would not only be when it is the pollutant agent (e.g. in road construction, landfills, and others, without having an environmental impact study carried out), but, also, by its omission when it has the constitutional duty to protect the environment (e.g. ceases to oversee, not comply to the informational rules on licensing processes, etc.) [13]

Édis Milaré sustains that "the State can also be jointly and severally liable for environmental damage caused by third parties, since it is its duty to control and prevent them from happening". In such cases, the legal entity of public law shall be responsible to file a return action against the direct causer of the damages. [13]

Holding the State accountable, ultimately, the whole society responds, in a way that the State responsibility should only be sought when it cannot identify the person under private law who causes environmental damage.[19]

As a result, the joint State liability can only be carried in a subsidiary manner, and the State could invoke the benefit of privilege, own (inherent) to the subsidiarity principle. [13]

\section{Civil Liability For Nuclear Damages}

The protection of the environment as a result of nuclear activities, in Brazil, was first foreseen in the Decree-Law 1,809 [20] of October 7, 1980, which established the Protection System for the Brazilian Nuclear Program, which created the duty of the Public Power to apply environmental protection measures through SIPRON. [21]

The decree-law only mentioned the protection, but, it did not attribute any liability for damages caused to the environment.

The Federal Constitution, in article 21, item XXIII, letter " $d$ ", established that the civil liability for nuclear damages does not depend on fault:

Article 21 (...)

d) civil liability for nuclear damage does not depend on the existence of a fault. [7]
According to Celso Antônio Pacheco Fiorillo, on account of the provisions of the above-mentioned article, it would be a case of objective liability, without the possibility of applying any kind of exclusion of liability (even fortuitous event or force majeure). [22]

However, as can be seen from the very letter of the Constitution, there is no express provision of impossibility to apply exclusions. On the contrary, FC / 88 does not restrict, only imposes the objective liability.

Furthermore, as explained in item 4.2., in liability for environmental damage uses the argument of legal hermeneutics to justify the theory of integral risk, i.e. any exception to the rule must be expressly provided by law and, as in environmental or related legislation there is no provision for exclusion of liability for environmental damage, it is not possible to extend to the Environmental Law, the exclusion of liability provided for the Private Law. Thus, this same argument of hermeneutics can be used in the case of nuclear damage, since, as will be seen, there are exclusion of liability expressed in the law for nuclear damage.

Civil liability for nuclear damage, even before the Federal Constitution, was already forecast in art. 4 of Law 6,453 / 1977 [23].

Some reservations are required:

1st - the mentioned law lists the cases in which the operator will be held responsible regardless of fault;

2nd - according to art. 6 of the law, if proven that the damage resulted from the victim's exclusive fault, in relation to it, the operator shall be discharged from the obligation to indemnify.

3rd -art. 8 establishes exclusion of liability of the operator if the damage results from a nuclear accident caused directly by armed conflict, hostilities, civil war, insurrection, or exceptional fact of nature.

Therefore, taking into account several particularities, it can be verified that for nuclear damage the objective liability cannot, as many claim, be derived from the theory of integral risk in the molds delimited by the doctrine.

It should be highlighted that the Law 6,453 / 1977 was not declared unconstitutional (for non-receipt by the Federal Constitution of 1988) and, in addition, Decree No. 911/1993 [24] (subsequent to the FC / 88) promulgated, without reservations, the Vienna Convention on Civil Liability for Nuclear Damage, dated May 21, 1993, bringing almost the same sayings as the Law 6,453 / 1977.

It is noted, consequently, that there are exclusions of liability in the case of nuclear damage.

Carlos Alberto Bittar asserts that, regarding nuclear activities, there is a special legal regime of civil liability, which is a system called "nuclear risk theory", which would be: "dominated by the idea of socialization of risks, with the intense and decisive participation of the State in the process where the victim represents the center of concern.” [3]

Still, according to the mentioned author, it is a regime informed by its own principles, solidified in the Paris Convention of July 12, 1960. Such principles would break the classic molds of civil liability and would be constructed on the grounds of the "notions of the need for nuclear risk to society and the 
indispensability of its protection. (...) The principles are as follows: the principle of 'channeling' responsibility; the limitation of liability; the responsibility for the exercise of the activity; the grounds in risk; the obligation of prior guarantee; of the binding (direct or subsidiary) of the State to the payment of compensation.” [3]

For Bittar, the operator of the nuclear activity shall be civilly liable due to the inherent dangerousness of the activity, in a way that the objective theory reaches the broader connotation, not including the presumption technique. The rationale for such liability would be the theory of risk, whereby the operator of the activity bears the burdens arising from it and, because of the danger degree, the risk must be taken in the strictest sense, covering cases of fortuitous event or force majeure, only admitting as exclusions of liability facts of exceptional gravity, such as armed conflicts, extreme natural cataclysm, etc. [3]

It is noteworthy that there is no need for the practice of an illicit act to generate the duty to indemnify in this case. The responsibility stems from the mere exercise of the activity.

Thus, despite that the majority doctrine includes civil liability for nuclear damages in the category of objective liability for integral risk, this is not the reality of our legislation.

\section{CONCLUSION}

As seen, the civil liability of the State is objective, based on the theory of administrative risk, which admits excluding and mitigating liability. However, when it comes to liability for environmental damage, the majority doctrine understands that the liability would be based on the theory of integral risk, which does not admit any exclusion of liability.

The liability based on the theory of integral risk is the one adopted by the "STJ" (Superior Court of Justice), which, however, requires the causal link to exist the duty to repair.

If the theory of risk created (or of activity risk) is adopted, the allegation of exclusions of liability would be possible.

Whatever the theory adopted, although solidarity is the predominant understanding in cases of reparation for environmental damages, when it comes to the State's liability, it should be triggered only when the accountability of the direct causer of the damages is absolutely impossible, because when the State is held responsible, so is the society as a whole, and in such cases the State should be called to answer only subsidiarily.

Regarding environmental damage caused by nuclear activities, as it can be observed, there are specific regulations for which liability is objective by constitutional force, however, admitting exclusions of liability in law and decree.

Thus, although the majority of doctrines affirms that nuclear damage, due to its high risk, should be considered, in the strictest sense, the greatest example of responsibility, in accordance with the theory of integral risk this is not possible if the country order is observed since in a positivist system as long as the norms that foresee the exclusions are not declared unconstitutional, they remain in force and should be applied.

\section{REFERENCES}

1. E. N. de Araújo, Curso de direito administrativo, $8^{\text {a }}$ ed., São Paulo, Brasil: Saraiva Educação, 2018. (E. N. de Araújo, Administrative law course., 8th ed., Sao Paulo, Brazil: Saraiva Education, 2018).

2. Y.S. Cahali, Responsabilidade civil do Estado, $4^{\text {a }}$ ed., São Paulo, Brasil: Revista dos Tribunais, 2012.

(Y. S. Cahali, State's civil liability, 4th ed., Sao Paulo, Brazil: Journal of the Courts, 2012).

3. C. A. Bittar, Responsabilidade civil nas atividades nucleares, São Paulo, Brasil: Revista dos Tribunais, 1985 .

(C. A. Bittar, Civil liability in nuclear activities, Sao Paulo, Brazil: Journal of the Courts, 1985.)

4. F. Tartuce, "Responsabilidade civil," em Manual de Direito Civil: volume único, $9^{\mathrm{a}}$ ed., São Paulo, Brasil: Método, 2019, cap. 4, seç. 4.3.3.1, págs. 393 - 470.

(F. Tartuce, "Civil responsibility," in Civil Law Manual: single volume, 9th ed., Sao Paulo, Brazil: Method, 2019, ch. 4, sec. 4.3.3.1, pp. 393 - 470.) Retrieved from:

https://www.academia.edu/31961479/Manual de Direito Civil Volume Unico Flavio Tartuce

Retrieved on: Apr. 10, 2019

5. $\quad$ Presidência da República. (10.1.2010). Lei $n^{\circ} 10.406$ Institui o Código Civil art. 945.

(Presidency of the Republic. (Jan. 10, 2010). Law no. 10.406 Institutes the Civil Code art. 945.)

Retrieved from:

http://www.planalto.gov.br/ccivil 03/leis/2002/l10 406.htm?fbclid=IwAR1nFCh-

8euJDghoZNKoTazsMUaDzFmgitZ4JMgcrepl7Q4CZLFpmygrO4

Retrieved on: Apr. 10, 2019

6. N. Hungria, Comentários ao Código Penal, vol. 1, Tom. 2, $3^{\text {a }}$ ed., Rio de Janeiro, Brasil: Revista Forense, 1955, Arts. 11 a 27.

(N. Hungria, Comments on the Penal Code, vol. 1, Tom. 2, 3rd ed., Rio de Janeiro, Brazil: Forense Magazine, 1955, Arts. 11 to 27.)

7. Presidência da República. (05.10.1988). Constituição da República Federativa do Brasil de 1988. (Presidency of the Republic. (Oct. 5, 1988). Constitution of the Federative Republic of Brazil, 1988.)

Retrieved from:

http://www.planalto.gov.br/ccivil 03/constituicao/ constituicao.htm

Retrieved on: Mar. 22, 2019

8. Presidência da República. (10.1.2002). Lei no 10.406 Institui o Código Civil.

(Presidency of the Republic. (Jan. 10, 2002). Law no. 10.406 Establishes the Civil Code.)

Retrieved from:

http://www.planalto.gov.br/ccivil_03/leis/2002/l10 406.htm

Retrieved on: Apr. 13, 2019

9. H. L. Meirelles, "Responsabilidade civil da administração," em Direito Administrativo Brasileiro, 42 ${ }^{\mathrm{a}}$ ed., São Paulo, Brasil: Malheiros, 2016, cap. 10, seç. 1, p. $779-792$.

(H. L. Meirelles, "Civil liability of the administration," in Brazilian Administrative Law, 42nd ed., Sao Paulo, Brazil: Malheiros, 2016, ch. 10, sec. 1, p. 779 - 792.)

Retrieved from:

https://libgen.is/book/index.php?md $5=4055$ Do0 32 7A90FF80D397AD18960E99F

Retrieved on: Apr. 13, 2019 
10. E. Freitas, “Teorias do Risco,” Jusbrasil, 03.11.2015. (E. Freitas, "Risk theories," Jusbrasil, Nov. 3, 2015.) Retrieved from:

https://eleniltonfreitas.jusbrasil.com.br/artigos/250 $\underline{885109 / \text { teorias-do-risco }}$

Retrieved on: Mar. 15, 2019

11. Superior Tribunal de Justiça. (18.3.2015). $n^{\circ} 30$ Direito Ambiental.

(Superior Justice Tribunal. (Mar. 18, 2015). no. 30 Environmental Law.)

Retrieved from:

http://www.stj.jus.br/internet_docs/jurisprudencia/ jurisprudenciaemteses/Jurisprud\%C3\%AAncia\%20e m\%20teses\%2030\%20-

\%20direito\%20ambiental.pdf

Retrieved on: May 22, 2019

12. P. F. I. Lemos, Direito ambiental: responsabilidade civil e proteção ao meio ambiente, $3^{\mathrm{a}}$ ed., São Paulo, Brasil: Revista dos Tribunais, 2010.

(P. F. I. Lemos, Environmental law: civil liability and protection of the environment, 3rd ed., Sao Paulo, Brazil: Journal of the Courts, 2010.)

13. É. Milaré, "Responsabilidade civil ambiental," em Direito do ambiente, $11^{\mathrm{a}}$ ed., São Paulo, Brasil: Thomson Reuters, 2018, cap. 2, seç. 4.2, pp. $430-$ 522.

(É. Milaré, "Environmental liability," in Environmental law, 11th ed., Sao Paulo, Brazil: Thomson Reuters, 2018, ch. 2, sec. 4.2, pp. $430-$ 522.)

Retrieved from:

http://www.mpsp.mp.br/portal/page/portal/docum entacao e divulgacao/doc biblioteca/bibli servico s produtos/bibli boletim/2019 Boletim/Bolo5 04 .pdf

Retrieved on: Apr. 13, 2019

14. J. L. G. de Almeida, Temas atuais de responsabilidade civil, São Paulo, Brasil: Atlas, 2007.

(J. L. G. de Almeida, Current issues of civil liability, José Luiz Gavião de Almeida, Sao Paulo, Brazil: Atlas, 2007.)

Retrieved from:

https://repositorio.usp.br/item/002194592

Retrieved on: Mar. 22, 2019

15. Presidência da República. (28.3.1977). Decreto $n^{o}$ 79.437 Promulga a Convenção Internacional sobre Responsabilidade Civil em Danos Causados por Poluição por óleo, 1969.

(Presidency of the Republic. (Mar. 28, 1977). Decree no. 79.437 Promulgates the International Convention on Civil Liability for Oil Pollution Damage, 1969.)

Retrieved from:

http://www.planalto.gov.br/ccivil_03/decreto/19701979/D79437.htm

Retrieved on: Apr. 13, 2019

16. Presidência da República. (31.8.1981). Lei $n^{\circ} 6.938$ Dispõe sobre a Política Nacional do Meio Ambiente, seus fins e mecanismos de formulação e aplicação, $e$ dá outras providências.

(Presidency of the Republic. (Aug. 31, 1981). Law no. 6,938 Provides for the National Environmental Policy, its purposes and mechanisms of formulation and application, and other measures.)

Retrieved from: http://www.planalto.gov.br/ccivil 03/leis/16938.ht $\underline{\mathrm{m}}$

Retrieved on: Apr. 13, 2019
17. S. L. Henkes, "A Responsabilidade Civil no Direito Ambiental Brasileiro," Revista de Direito Sanitário, v. 10, n. 1, págs. 51 - 70, Mar./Jul. 2009.

(S. L. Henkes, "The Civil Responsibility in the Brazilian Environmental Law," Health Law J., vol. 10, no. 1, pp. 51 - 70, Mar./Jul. 2009.)

DOI: $10.11606 /$ issn.2316-9044.v10i1p51-70

18. C. R. Gonçalves, Direito Civil Brasileiro: responsabilidade Civil, vol. 4, 10 ${ }^{\mathrm{a}}$ ed., São Paulo, Brasil: Saraiva, 2015 .

(C. R. Gonçalves, Brazilian Civil Law: Civil Liability. vol. 4, 1oth ed., Sao Paulo, Brazil: Saraiva, 2015.)

19. S. S. Venosa, Direito Civil: obrigações $e$ responsabilidade civil, vol. 2, $17^{\mathrm{a}}$ ed., São Paulo, Brasil: Atlas, 2017.

(S.S. Venosa, Civil Law: obligations and civil liability, vol. 2, 17th ed., Sao Paulo, Brazil: Atlas, 2017.)

Retrieved from:

http://93.174.95.29/ ads/C4C10068CF480095FB6 o87C46D89Bo92

Retrieved on: Apr. 13, 2019

20. Presidência da República. (o7.10.1980). Decreto-Lei $n^{o} 1.809$ Institui o Sistema de Proteção ao Programa Nuclear Brasileiro, e dá outras providências (Revogado pela Lei $n^{o}$ 12.731, de 2012).

(Presidency of the Republic. (Oct. 7, 1980). DecreeLaw no. 1,809 Establishes the System of Protection to the Brazilian Nuclear Program, and other measures [Repealed by Law no. 12,731 of 2012]).

Retrieved from:

http://www.planalto.gov.br/ccivil 03/DecretoLei/1965-1988/Del1809.htm

Retrieved on: Apr. 13, 2019

21. A. Tostes, Sistema de legislação ambiental, Petrópolis, Brasil: Vozes/CECIP, 1994.

(A. Tostes, System of environmental legislation, Petropolis, Brazil: Voices/CECIP, 1994.)

22. C. A. P. Fiorillo, Curso de Direito Ambiental Brasileiro, 19 ${ }^{\mathrm{a}}$ ed., São Paulo, Brasil: Saraiva Educação, 2019.

(C. A. P. Fiorillo, Brazilian Environmental Law Course, 19th ed., Sao Paulo, Brazil: Saraiva Education, 2019.)

23. Presidência da República. (17.10.1977). Lei $n^{o} 6.453$ Dispõe sobre a responsabilidade civil por danos nucleares e a responsabilidade criminal por atos relacionados com atividades nucleares e dá outras providências.

(Presidency of the Republic. (Oct. 17, 1977). Law no. 6,453 Provides for civil liability for nuclear damage and criminal liability for acts related to nuclear activities and other measures.)

Retrieved from:

http://www.planalto.gov.br/ccivil_03/Leis/L6453.h $\underline{\mathrm{tm}}$

Retrieved on: Mar. 22, 2019

24. Presidência da República. (03.9.1993). Decreto $n^{o} 911$ Promulga a Convenção de Viena sobre Responsabilidade Civil por Danos Nucleares, de 21/05/1963.

(Presidency of the Republic. (Sep. 3, 1993). Decree no. 911 Promulgates the Vienna Convention on Civil Liability for Nuclear Damage of May 21, 1963.) Retrieved from: http://www.planalto.gov.br/ccivil 03/decreto/1990 -1994/Do911.htm

Retrieved on: Mar. 22, 2019 